\title{
青森県における新生児聴覚スクリーニングに 関するアンケート調査
}

\author{
籾山淳子 ${ }^{12)}$, 南場淳司 ${ }^{1)}$, 阿部尚央 ${ }^{1)}$, 新川秀一1) \\ ${ }^{1)}$ 弘前大学医学部耳鼻咽喉科学教室 \\ 2)秋田県大館市立総合病院耳鼻咽喉科
}

\begin{abstract}
要旨：新生児聴覚スクリーニング（以下スクリーニング）は全国的に実施率が増加傾向に ある。今回我々は青森県内産科施設に対し，アンケート調査を行い，スクリーニング状沉 を調查した。結果, 産科施設の 6 割が検查機器を保有しており, 県内でも地域差が認めら れた。さらに $\mathrm{H} 16$ 年, 17 年の県内スクリーニング施行症例数の概算と, 同年の県の出生数 から求めるスクリーニング実施率は約 $25 \%$ あり, 全国の報告からしても低いという結果 であった。機器を持たない施設では経済的, 人手不足の問題から, 今後も導入予定がない という回答であり, 青森県での実施率向上には, 機器保有施設での全例施行, または機器 のない施設での出生児を機器保有施設で検査するなどの対策を検討するべきではないかと 思われた。今後は検査実施率の向上に向け，産婦人科，小児科と更なる協力体制をと考え ている。
\end{abstract}

$$
\text { ーキーワードー }
$$

新生览聴覚スクリーニング, 機器保有状況, 実施率

\section{はじめに}

日本における新生児聴覚スクリーニングは平成 13 年度より厚生労働省のモデル事業が始まり，その後 全国的に広まった。行政の援助を受けたスクリーニ ング（以下公的スクリーニングと記す）が行われた 地域がある一方で，そういった支援のない地域では スクリーニングのシステム作りがいまだ進んでいな い地域も多い。青森県は後者に含まれるが，弘前大 学医学部耳鼻咽喉科学教室 (以下当科) では平成 15 年ごろから弘前市の産婦人科施設と協力し, 新生児 聴覚スクリーニングのシステム作りに取り組み, 弘 前方式新生览聴覚スクリーニングを行っている。青 森県も公的スクリーニングが行われていない他の地 方自治体と同様，それぞれの産科施設における判断 で，新生児聴覚スクリーニングが導入されこれまで 検査が行われてきた。全国的に新生児聴覚スクリー
ニングにおける難聴児早期発見における有用性が周 知されたことで, 青森県でも検查症例数が徐々に増 えたためか，ここ数年で当科を受診する refer 児の 数も増加してきている。しかしながら，これまで青 森県におけるスクリーニング実施率についての検討 は無く, 我々も実際に県内でどのように新生児聴覚 スクリーニングが行われているのかについては把握 していなかった。今回は弘前大学医学部産婦人科教 室の協力を得て, 県内の産婦人科施設を対象に, 新 生児聴覚スクリーニング機器の保有状況について調 査するとともに，実際にどのように行われているの かについてアンケート調査を行ったので, 集計結果 に検討を加え報告する。

\section{対象と方法}

平成19年 6 月の時点で産科施設を有する青森県の 36 施設（助産院 3 箇所は除く）を対象にアンケート 
調查を施行した。アンケート調査は13項目とし，ア ンケート用紙を郵送し, 当科へFAXで返信する形 で回答を得た。

アンケートの内容は表 1 に示した。質問内容は新 生児聴覚スクリーニング機器の保有の有無で異なる ものにした。機器を保有する場合は, 機器の内容, 導入時期, 検査対象児の選択方法, 検査時期, 検査 担当者, refer 児への対応，平成16年と 17 年のスク リーニング症例数, 同時期に施設で出生した症例数 における検查児の割合，同時期に最終的に専門機関
へ紹介を要した症例数について質問した。また，保 有していない場合は今後導入予定の有無について質 問し，予定の無い場合はその理由，予定があれば導 入予定機器は何かについても質問した。また最後に 自由欄を設け，新生児スクリーニングに関する意見 や要望についても記入できる形式にした。このアン ケートにより, 県内の分婏取り扱い施設の分布状況 を把握し，その施設での新生児聴覚スクリーニング 機器の保有状況, スクリーニングの実態がわかるも のと考えた。

表 1 アンケート用紙の質問内容

Q 1. 貴院では新生児聴覚スクリーニングの機器を所有していますか。
1.はい $\rightarrow \mathrm{Q} 2 \sim \mathrm{Q} 11 へ$
2.いいえ $\rightarrow$ Q12〜Q13へ

Q 2.その機器は以下のいずれでしょうか。
1. $\mathrm{OAE}$
2.自動 ABR
3 . 両方

Q 3 .そのメーカーと機器の名称を教えてください。

例：日本光電の MAAS (echo-screen II シリーズ)

Q 4 . 新生児聴覚スクリーニングを導入された時期を教えてください。
平成
年
月から

Q 5 . 新生児聴覚スクリーニングの対象はどのように選択していますか。

1 . 貴院での出生児全症例

2 . 希望者のみ

3 ，ハイリスク児のみ

4. その他（具体的に

Q 6 . 新生児聴覚スクリーニングを施行する時期はいつですか？
1 . 生後
日目と決めている。
2 . 生後
日目から退院までの間としている。
3 . その他（具体的に

Q 7. 検查は誰が行っていますか?
1. 医師
2、看護師または助産師
3 . 検查技師
4. その他（具体的に

Q 8. 新生児聴覚スクリーニングで refer となった場合どのように対処していますか？

1. 1 回目で referであれば，耳鼻科へ紹介する。

2、再検しても referであれば，耳鼻科へ紹介する。

3 . 説明のみで特に紹介しない。

4. その他（具体的に 
Q 9 . 以下の期間に貴院で新生児聴覚スクリーニングを受けた症例数を教えてください。

平成16年 1 月から 12 月末まで

平成17年 1 月から12月末まで

例)

Q10. 以下の期間に貴院での出生された症例総数のうち，スクリーニングを受けた症例の割合を教えてく ださい。

平成16年 1 月から 12 月末まで $100 \%$ or（具体的に \%)

平成17年 1 月から 12 月末まで $100 \%$ or（具体的に \%)

Q11.スクリーニングの結果 refer となり最終的に専門機関への紹介が必要となった，あるいは受診を促 した症例数を教えてください。

平成16年 1 月から 12 月末まで

平成17年 1 月から 12 月末まで

Q12. 貴院で今後新生児聴覚スクリーニングの導入予定はありますでしょうか。

1.ある 2 。ない（理由：

Q13. Q12で予定がある場合，機器はどちらを考えていますか？

1. OAE 2 . 自動 ABR 3 . 両方

その他，新生児聴覚スクリーニングに関するご意見，ご要望などございましたら，ご記入ください。

以上ご協力ありがとうございました。

\section{結果}

1.スクリーニング機器の保有状況

アンケートの回答を得られたのは32施設であっ た。回答を得られなかった 4 施設には電話で機器保 有の有無について問い合わせした。アンケートの回 答を得られた 32 施設のうち, 分娩の取り扱い施設が 29施設，うちスクリーニング機器を保有していたの は19施設, 無いところが10施設であった。また分娩 を休止している施設が 3 施設あった。電話で問い合 わせた 4 施設の回答は自動 ABR を持つ施設が 1 施 設, 機器の無い施設が 2 施設, 分娩休止が 1 施設で あった。従って, 県内の分娩取り扱い施設は計 32 施 設であり，そのうち，スクリーニング機器を保有す
る施設は20施設，機器の無い施設は12施設であっ た。また，県内の分娩取り扱い施設の分布と，機器 保有状況を図 1 にまとめた。

2. スクリーニング機器の種類

スクリーニング機器を所有していた 20 施設の中 で，自動 $\mathrm{ABR}$ と OAE が同数で 8 施設，両方を有 すると答えた施設は 4 施設であった（図 2 )。ま た，両者を有する 4 施設において，OAEを導入後， 自動 $\mathrm{ABR}$ を追加した個人施設が 2 施設で，総合病 院が 2 施設であった。

3 . 機器導入の時期

検査の導入時期としてはもっとも早かった施設は 平成 12 年 1 月であり，県内の新生照聴覚スクリーニ ングが初めて行われるようになってから，約 7 年が 


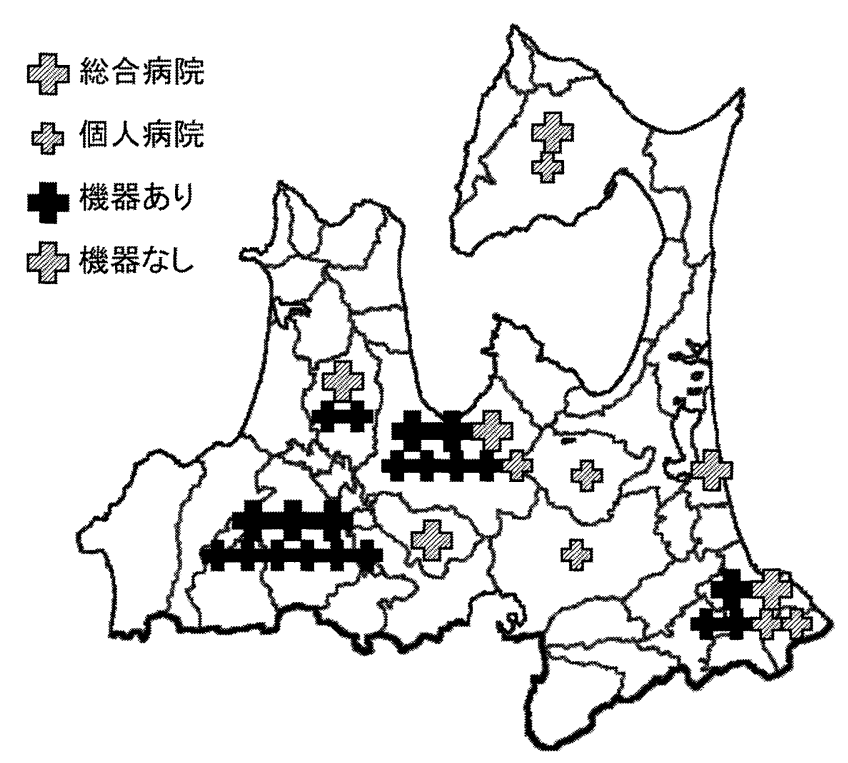

図 1 分婏取り扱い施設の分布

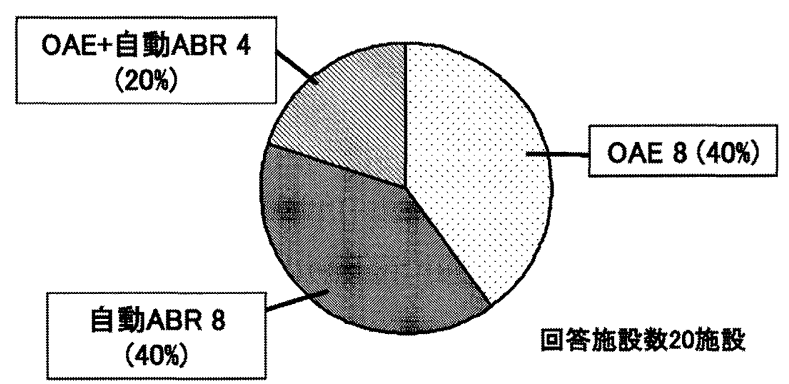

図 2 スクリーニング機器の内訳

経過していることがわかった。機器導入施設は毎年 順調に増加しており，平成18年以降に機器を導入し た施設は 3 施設あった。

4. 検査対象症例の選択

スクリーニング対象者の選択方法は，新生児の全 例に実施するところが11施設，希望者のみが 6 施 設，ハイリスク児のみが 2 施設であった（図 3 )。

5 . 出生数に対する検査児の割合

平成16年と 17 年の各施設における出生児に対す る，検査児の割合についての回答結果は，ほほ $100 \%$ としたのが11施設であった。希望者のみとしている 6 施設で，回答のあった 4 施設中 2 施設では新生児 の約 4 割に検査が行われ，他の 2 施設ではその約 8 割に実施されていた。ハイリスク児のみ検査を行っ ている 2 施設はNICUをもち全県でもハイリスク の分婏が集中する施設であった。

6 . 検査施行時期

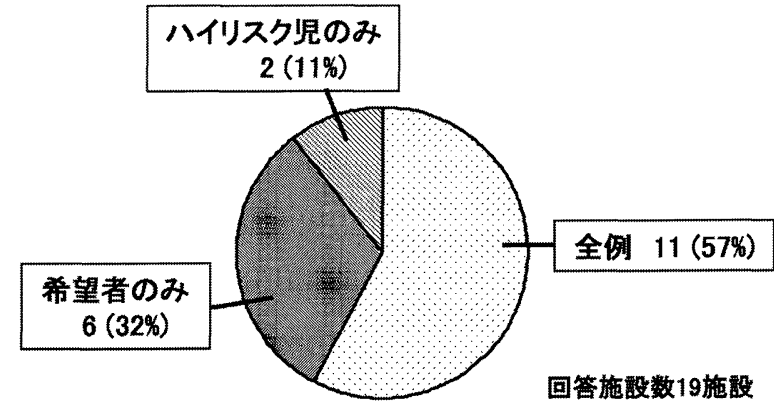

図 3 対象症例の選択

表 2 検查実施時期

\begin{tabular}{||l|l||}
\hline & 施設数 \\
\hline 生後 3 日目と決めている & $5(\mathrm{OAE}-2$ 自動 $\mathrm{ABR}-2$ 両方-1) \\
\hline 生後 1 日目から退院までに & $1($ 自動 $\mathrm{ABR})$ \\
\hline 生後 2 日目から退院までに & $3($ 自動 $\mathrm{ABR}-2$ 両方-1) \\
\hline 生後 3 日目から退院までに & $3(\mathrm{OAE}-1$ 自動 $\mathrm{ABR}-1$ 両方-1) \\
\hline 生後 4 日目から退院までに & $3(\mathrm{OAE}-1$ 自動 $\mathrm{ABR}-2)$ \\
\hline 生後 5 日目から退院までに & $2(\mathrm{OAE}-2)$ \\
\hline その他 & $2(\mathrm{OAE}-1$ 両方-1) \\
\hline
\end{tabular}

検査施行時期については生後 3 日目と決めている ところが 5 施設であり，多くの施設は生後から退院 までの入院中に検査を行っていた。すなわち，生後 1 日目以降としているところが 1 施設， $2 ， 3 ， 4$ 日目以降が各々 3 施設，5 日目以降が 2 施設，その 他が 2 施設であった。それぞれの検査施行時期にお けるスクリーニング機器の詳細を表 2 に示す。 


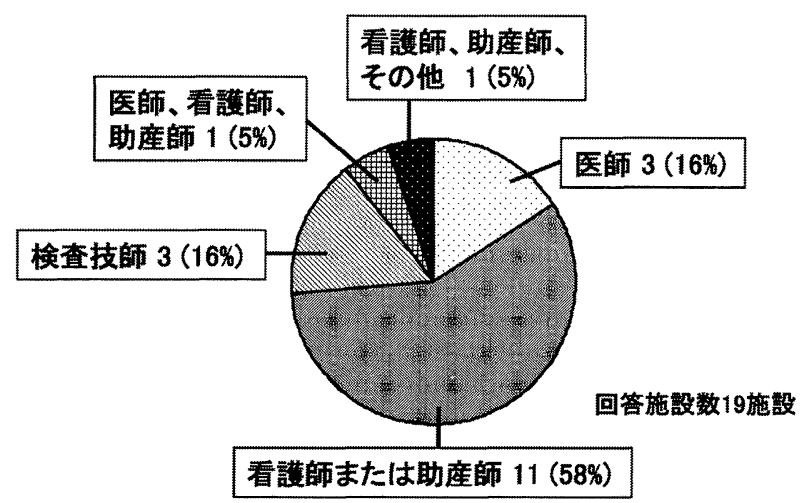

図 4 検查担当者の内訳

\section{7 . 検査担当者}

検査担当者は医師が 3 施設であり，看護師または 助産師が最も多く11施設, 検查技師が 3 施設, 医師 または看護師, 助産師が 1 施設, 看護師, 助産師, その他と回答したところが 1 施設であった。(図 4)

8. refer 览への対応

1 回目の検査で referであれば紹介すると回答し た施設はなかった。再検しても referであれば耳鼻 科へ紹介すると回答したところが14施設あり，小児 科へ紹介するところが 2 施設, 近医で自動 ABR の 検查可能な施設へ紹介するとした施設が 1 施設, 紹 介先は Dr の判断と回答したところが 1 施設であっ た。説明のみで紹介はしないところが 1 施設あっ た。(図 5 )

\section{9. スクリーニング症例数}

平成 16 年と 17 年の各 1 年間において, 新生览聴覚 スクリーニングを受けた症例数は実数で回答が得ら れたところは, 機器保有施設20施設のうち14施設で あった。他の 6 施設は概算数での提示が 1 施設, 回 答無しが 2 施設，H18年以後に機器導入が 2 施設, $\mathrm{H} 18$ 年以後に開院が 1 施設であった。その14施設で のスクリーニングを受けた児の総数は平成 16 年 2,576 人，平成 17 年 2,592 人，概算での提示した施設 は平成 16 年と 17 年がそれぞれ数十例ずつ。それぞれ の同時期の出生数は平成 16 年が 11,554 人, 平成 17 年 が 10,524 人であった。回答を得られなかった 2 施設 の毎年の出生数は平均 400 人前後と 300 人前後。その うち 1 施設は希望者にのみ検査をしているとの回答 であり，他方は電話で機器保有についてのみ回答し た施設であった。以上のことからスクリーニングを 受ける児は約 3000 人程度, 青森県の出生児に対する

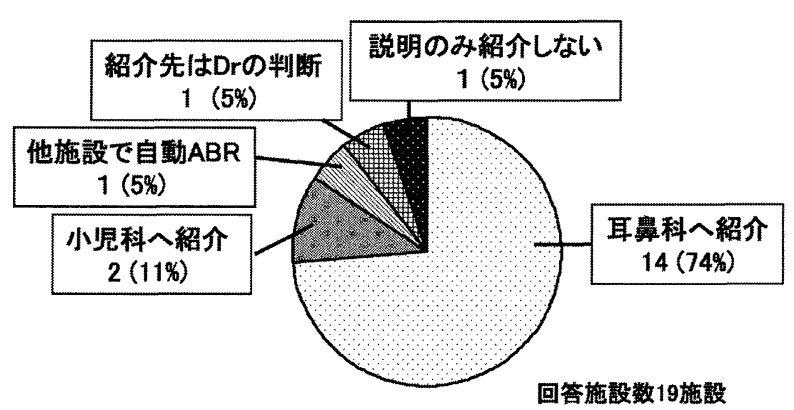

図 5 refer 巟への対応

スクリーニング実施率は約 $25 \%$ 程度ではないかと推 測された。

10. 精查施設への紹介

referにより専門施設（近医耳鼻科，小児科を含 める）に紹介した児の数は回答を得られた14施設の 合計で平成16年は 3 名, 平成 17 年は 7 名という結果 であった。

11. スクリーニング機器を保有しない施設

スクリーニング機器を所有していない12施設 中，10施設よりアンケートの回答が得られた。今後 のスクリーニングの導入予定についての質問につい ては，10施設すべてにおいて導入予定がないとの回 答であった。その主な理由はコストの問題が 5 施 設，検査後の紹介 $\rightarrow$ 精査 $\rightarrow$ 療育システムの不備を挙 げた施設が 3 施設, 人手不足 2 施設, 検査を誰が担 当するかが問題としたのが 1 施設であった（複数回 答含む)。

\section{考察}

今回の検討で県内における新生児聴覚スクリーニ ングが行われるようになってから約 7 年が経過して いることがわかった。その間，当科では壟学校との 連携体制を強め，小监の人工内耳を開始し，常勤の 言語聴覚士の配備など，小览難聴の療育体制を整え ることに力を注いできた。また，弘前市内の産科施 設, 言語訓練施設, 襲学校と協力し, 弘前方式新生 児聴覚スクリーニングを開始してから約 4 年が経過 した。弘前方式新生児聴覚スクリーニングでは, OAEで referであれば，再検查は自動 ABR をつ 周辺産科協力施設へ誘導し, さらに自動 $\mathrm{ABR}$ でも refer であれば，当科へ紹介する。あるいは自動 ABR 


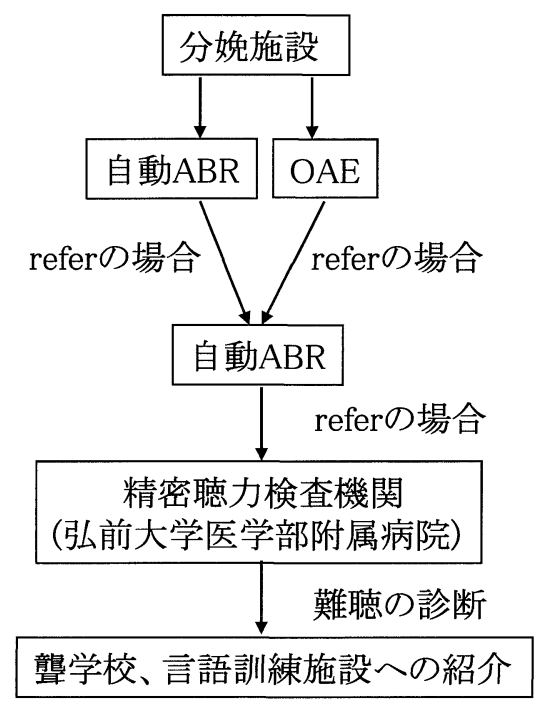

図 6 検查実施時期

を有する施設においては 1 回目で referであれば同 施設で再検查し，referであれば，当科へ紹介する というシステムにしている（図6）。これにより， 偽陽性率の低下，必要症例は早期から精査機関を受 診できるというメリットがある。またこの新生児聴 覚スクリーニングについて記載された用紙を母子手 帳配布時に一緒に妊婦に渡すことで情報を提供して いる。この用紙にはスクリーニング機器を保有する 施設の施設名をあげ，無い施設で分娩をしたとして も，協力施設でスクリーニングを受けられることを 明記している。このシステムが運営されるようにな り, 弘前市内の分婏取り扱い施設と当科との連携は 徐々に軌道に乗ってきているが，県内全体における スクリーニング現状はこれまで不明であった。

今回のアンケート調查の結果, 県内の分娩取り扱 い施設の分布と, スクリーニングの機器保有状況が 把握できた。その結果，県内の分婏取り扱い施設の うち約 6 割がスクリーニング機器を保有していた。 これは2002年増田ら ${ }^{1)}$ の三重県で行われた産婦人科 施設に対するアンケート調査で機器を導入施設と導 入を予定している施設をあわせると $56.6 \%$ あったた という報告，2007年千葉ら ${ }^{2)}$ の山形県における同様 のアンケート調查結果の実施施設の割合 $34.4 \%$ と比 較すると，我々の予想以上に高い割合であった。今 回の我々の調査で特に弘前市内ではすべての施設で 機器を導入していることがわかった。これは先に述 ベた弘前方式新生览聴覚スクリーニングを実施後，
産婦人科施設における検査の有用性の理解が深まっ たことが一因であり，また妊婦への情報提供の結 果，検查希望が高まった結果であろうと推測してい る。2004年山口らの報告 ${ }^{3}$ によると，同施設におけ る新生児聴覚スクリーニングに対する保護者の同意 率は，1998年の49.4\%から2002年の83.6\%まで増加 しており，スクリーニングに対する保護者の関心の 高まりがうかがえるとしている。我々は弘前方式新 生児聴覚スクリーニング開始時期と今回調査を比較 し，弘前市内における機器保有率の増加にはこの妊 婦からの希望増加も大いに影響したのではないかと 推察している。また今回，施設の分布図を作成する ことにより，県の西側においてスクリーニング機器 を持たない分娩施設が多いということがわかった。 2007年千葉 $5^{2)}$ も山形県内 4 地方のうち庄内地方以 外の地域でスクリーニング実施施設が少ない傾向に あり，県内でもばらつきがあったことを報告してい る。また今後はこの 3 地方のスクリーニング施設数 の増加が県内のスクリーニングカバー率の向上につ ながると考えていると述べている。スクリーニング を受けていない症例が多い地域では，乳幼児健診の 時点で難聴児の発見が重要となってくる。今回の 我々の調査結果は青森県内のスクリーニング実施施 設の少ない地域における小览科医への重要な情報と なるだろう。

検查機器の種類は，一般には公的スクリーニング を導入している地方自治体では精度の高さから自動 $\mathrm{ABR}$ が選択される傾向にあるとされている ${ }^{3)}$ 。平成 18 年 3 月の日本産婦人科医会が報告した「新生児聴 覚スクリーニング検査に関する実態調查結果」4)に よると $\mathrm{H} 17$ 年に行った全国の施設に対するアンケー 卜調査の結果では $\mathrm{OAE}$ と自動 $\mathrm{ABR}$ の割合は，35\% と $58 \%$ ，両方が $6 \%$ ，不明 $1 \%$ あっった。県内のス クリーニング機器は $\mathrm{OAE}$ と自動 ABR はほぼ同数 であり, 機器の価格, 出生数と消耗品のコストの面 も考えて各施設が判断した結果であろうと考えた。 今回の調査では平成 16 年と 17 年の検査症例について 検討したが，同期間に当科に紹介された refer 児は 合計11名であり, OAE 保有施設で出生した症例も, 弘前方式にのっとって検査をうけているため，全症 例が最終的には自動 ABR で referであるとして当 科を紹介となっている。そのため今回の結果から機 
器ごとの精度の違いについては検討できないが，一 般的には OAE は偽陽性率が高いことが知られてい る。回数を重ねることで要再検率を減らすことが可 能であるとはいわれているが5)，2007年畠ら ${ }^{6)}$ の鳥 取県での検討結果によると，OAEを用いて 1 ケ月 検診までに複数回検査を重ねても OAEの偽陽性率

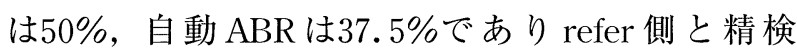
側との一致率を比較しても自動 ABRの精度が高か ったとしている。また 2007 年千葉ら も山形県にお ける検討結果で自動 $\mathrm{ABR} の$ refer 率は0.68\%, OAE の refer 率は $5.78 \%$ あ゙りこれまでの報告と同様, OAE の refer 率は自動 ABR より高かったと報告し ている。また山形県では「新生児聴覚検査事業の手 引き」で自動 ABR を推奨しており，今後スクリー ニングの制度向上のため自動 $\mathrm{ABR}$ 導入の必要性を 説明していくことが大切であると述べている。

偽陽性率の低下については今後の検討課題のひと つであるが，弘前方式はその手段の一つとして有用 であると考えており，全県で同様のシステムを行う 方向で検討していきたい。

検査症例の選択については全例に行っているとい う施設が半分以上を占め，これは我々の予想よりも 高い数值であった。ハイリスク児にのみ検査を行っ ている施設はNICUを持つ総合病院 2 施設であ り，はじめから従来の $\mathrm{ABR}$ を実施することが多 く，新生児聴覚スクリーニングとして自動 ABRや $\mathrm{OAE}$ を実施した症例数が少ないのではないかと推 察した。そのうちの 1 施設についてはアンケート調 查を機に全例施行に向け，準備態勢を整え，H19年 12月より全例施行が開始となっている。

検査施行時期についての検討では $\mathrm{OAE}$ のみ保有 の施設では生後 3 日目以降に行われており，生後ま もなくは外耳道や中耳腔の貯留物の影響を受けやす いことを考慮しているためと推察した。また生後早 期から検查する施設は自動 ABR を保有する施設で あり，これは referの場合，入院中に日を改めて検 査するための期間を得たいためと考えられた。

検查担当者はこれまでの報告と同様に看護師，助 産師の割合が大部分であり ${ }^{7)}$ ，検查技師が施行して いる病院は個人病院が 1 施設，総合病院が 2 施設で あった。検査導入に際しては，どの病院も人手不足 のため検查を誰が担当するかということが問題にな
る。特に総合病院の場合はこの問題が重要となる傾 向にあり, 導入が遅れる要因の一因とも言える。ま た検査方法は難しくなく簡便に行えるものである が，検査担当者が多人数になると，検査についての 理解度，熟練度の不足が危惧される7”。一般的には 数人程度が担当となり，当番で検査に当たることが 理想的と考えられており，検査精度を上げるために 今後検討が必要な内容のひとつであると思われた。

refer 览の紹介先として, 多くの施設が耳鼻咽喉 科を選択していたが，少数ながら小児科を選択して いる施設もあった。 $\mathrm{ABR}$ 可能な小児科もあるが, 補聴器装用についての判断, その後の療育のことも 考えれば，なるべく耳鼻咽喉科への紹介を勧めてい きたい。

今回のアンケート結果で青森県の新生児聴覚スク リーニング実施率は出生数の約 $25 \%$ 前後という結果 であった。現在スクリーニング機器を保有している 施設のなかで，平成18年以降に実施開始となった施 設が 3 施設あり，そのため分娩取り扱い施設数のう ち 6 割が機器を有するにもかかわらず，実施率が低 くなったのではないかと考えられる。前述の日本産 婦人科医会の報告(4)によるとスクリーニング害施率 は岡山県の $94 \%$ 最高に全国平均は $47 \%$ とされてい る。この報告では青森県の実施率は $57 \%$ とされてい るが，回答施設数が 7 施設であることから，今回の 我々の検討結果のほうがより実際の割合に近いと思 われる。青森県と同様に，公的スクリーニングが行 われていない鳥取県では，産科医，小児科医，耳鼻 咽喉科医，保健師，襲学校教師などからなる検討委 員会をたちあげ，平成17年度のスクリーニング実施 率は約70\%となったという報告があり ${ }^{6}$ ，今回の検 討では青森県における実施率の低さを実感する結果 となった。平成18年以降に検査開始施設が 3 施設あ ること，これまでハイリスク児のみに検査していた 施設も全例施行へ変わったことからも，今後は定期 的にこのような調査を行い，青森県における実施率 の変化についても把握していく必要を感じた。

今回検討した平成16年と17年に当科を紹介され受 診した症例数はそれぞれ 3 名，8名という結果であ り，精査が必要な症例は近医，小児科を経由しても 精査のために当科へ紹介されている結果であると考 察した。今後は患者家族の負担を十分考慮した診療 
体制を整え，受診例の増加に対応していく必要があ ると思われた。

スクリーニング機器を持たない施設の回答結果で は，その全施設で今後も導入予定がないという回答 であった。理由は今後の検討課題と重なる内容とな るものであり，また発見後の精査療育システムの不 備を指摘する声は想像していたより多く寄せられ た。当科は日本耳鼻咽喉科学会が認定する県内唯一 の 2 次精查機関であるが，降雪地域である青森県に おいては交通の便も考えると, refer となった場合， 全例当科を受診するというのは困難であるという意 見もあった。千葉ら ${ }^{2)}$ の報告でも，青森県と同様降 雪地域である山形県では地理的，交通面での問題は 避けては通れず冬季になるとその影響は大きい。こ れによりスクリーニング refer となったまま未受診 となるケースが危惧されるとしている。今後のシス テム作りにはこのような意見や考えも踏まえながら 検討していきたいと考えている。

以上の結果より，青森県における新生児聴覚スク リーニングにおいて今後の課題として次の 3 点が挙 げられる。

1. スクリーニング未施行の人数をどうやって減ら すか。

2. 偽陽性率の低下にはどうすればよいか。

3 . 紹介, 精査, 療育のシステム作りをどうするか。

1 については，機器がない施設での出生児を保有 施設に誘導し，どの施設でも一定の費用で検查でき るかたちが取れないか，という方向で検討してい る。弘前方式新生览聴覚スクリーニングの実績も踏 まえて，全県で同様に行えるよう検討していきた い。また，全例に検査を行っていない施設での実施 数を増やすためにも，妊婦，医療従事者に対する啓 蒙活動や理解を深める努力をしていく必要性を感じ た。

2 についてはどの施設も複数回検査したのちに精 查機関へ紹介するとしており，これは偽陽性率の低 下へ貢献していると評価した。できれば $\mathrm{OAE}$ と自 動 ABR を組み合わせた弘前方式を全県で行えるよ う，普及活動を継続したい。

3 については今回を契機として，産婦人科，小児 科医と協力し，近いうちに運営準備委員会を発足す る予定でいる。いずれは壟学校等の療育機関，保健
師なども加えて本格的な運営組織の活動を開始し， 県内のスクリーニング状況の把握，啓蒙活動，療育 機関とのさらなる連携をと考えている。

\section{まと め}

1. 県内の分娩可能な産婦人科施設のうち 6 割がス クリーニングの機器を有しており，OAEと自動 $\mathrm{ABR}$ は同程度の割合であった。

2. 青森県のスクリーニング実施率は約 $25 \%$ 程度と 非常に低かった。

3. 機器を有しない施設には地域の中核をなす公立 病院が半数含まれており，そういう地域には耳鼻 科医も少なく難聴児の発見が遅れることが危惧さ れる結果であった。

4. 今後は，産婦人科，小児科医とも協力し，青森 県内の新生児聴覚スクリーニングのシステムを明 確に作り上げる必要があると考えられた。

\section{謝辞}

今回のアンケート調査に関してご協力いただい た，水沼英樹教授，尾崎浩士准教授をはじめとする 当院産婦人科学教室の皆様, ならびに青森県内産婦 人科施設の諸先生方に深謝申しあげます。

\section{A questionnaire survey of the status of newborn hearing screening in Aomori}

Junko Momiyama ${ }^{122}$, Atsushi Namba ${ }^{1)}$, Takahisa Abe $^{1)}$, Hideichi Shinkawa ${ }^{1)}$

\footnotetext{
${ }^{1)}$ Department of Otorhinolaryngology, Hirosaki University graduate School of Medicine ${ }^{2)}$ Department of Otorhinolaryngology, Odate Municipal Hospital
}

Newborn hearing screening (NHS) programs have advanced nationally in Japan, however, differences have been seen in the funding, availability of equipment and rates of enforcement among prefectures. We investigated the current status of NHS in Aomori Prefecture by conducting a questionnaire survey of 36 obstetric institutions. About $60 \%$ per- 
formed NHS using automated auditory brainstem response $(\mathrm{AABR})$ or otoacoustic emission $(\mathrm{OAE})$ in equal numbers, while some institutions using both types of testing. Differences in the availability of testing devices were seen among institutions. About 3,000 (25\% of all) neonates were screened annually in 2004 and 2005. Compared to the national median, this is a low percentage. Institutions that lacked NHS devices indicated that they had no plans to purchase the equipment either, because of lack of funds and/or shortage of manpower.

Early identification of hearing impairment is important for language development. To increase the rate of NHS in Aomori prefecture, we believe that it is necessary for otorhinolaryngologists to gain the cooperation of obstetricians and pediatricians and encourage institutions with the facilities to perform testing on all the neonates born at the institutions, as well as facilitate the transfer of newborns from institutions without facilities for NHS to those that are equipped, so that these neonates can also undergo screening.

\section{参考文献}

1 ）増田佐和子, 鶴岡弘美, 間島雄一：三重県にお ける新生児聴覚スクリーニングへの耳鼻咽喉科医 の取り組み。Audiology Japan 47：222-227, 2004

2 ）千葉寛之, 伊藤吏, 渡辺知緒, 他 : 山形県の新 生児聴覚スクリーニングの現状と当科におけるス
クリーニング refer 児の精密聴力検査。Audiology Japan 50 : 218-224, 2007

3 ）山口暁, 都甲明子, 森田訓子：耳音響放射 (OAE) および自動聴性脳幹反応（Automated ABR）を利用した 2 段階新生児聴覚スクリーニン グ。産婦人科の実際 53:295-300，2004

4 ）日本産婦人科医会 : 新生児聴覚スクリーニング 検査に関する実態調査結果 : 2006

5 ）三科潤 : 新生児聴覚スクリーニング。産婦人科 治療 92：977-982，2006

6 ）畠史子, 長谷川賢作, 玉川友哉, 他：鳥取県に おける新生児聴覚スクリーニングおよび 3 歳児聴 覚検診の有効性の検討。Audiology Japan 50: 107-112, 2007

7 ）三浦正子，今本美智代，中津愛子，他：全国ア ンケート調査にみる新生児聴覚スクリーニングの 問題点。Audiology Japan 45：225-233, 2002

（原稿受付 平成20.7.11）

別冊請求先： $\mathbf{T} 017-8550$

秋田県大館市豊町 $3-1$

大館市立総合病院耳鼻咽喉科 籾山 淳子

\section{Reprint request :}

Junko Momiyama

Department of Otorhinolaryngology Hirosaki University School of Medicine

5 Zaifu-cho, Hirosaki city, Aomori, 036-8562, Japan 